\title{
Can Existing Theories Explain China's Outward Foreign Direct Investment in Belt and Road Countries
}

\author{
Le Chang ${ }^{1}\left(\mathbb{D}\right.$, Jing Li ${ }^{2} * * \mathbb{0}$, Kee-Cheok Cheong ${ }^{1}$ and Lim-Thye Goh ${ }^{1}(\mathbb{D}$ \\ 1 Faculty of Economics and Administration, University of Malaya, Kuala Lumpur 50603, Malaysia; \\ changle1984@siswa.um.edu.my (L.C.); keecheok1@yahoo.com (K.-C.C.); ltgoh@um.edu.my (L.-T.G.) \\ 2 Fashion Department of International United Faculty between Ningbo University and University of \\ Angers/Faculty of Geography Science and Tourism Culture, Ningbo University, Ningbo 315201, China \\ * Correspondence: lijing2@nbu.edu.cn
}

Citation: Chang, L.; Li, J.; Cheong, K.-C.; Goh, L.-T. Can Existing Theories Explain China's Outward Foreign Direct Investment in Belt and Road Countries. Sustainability 2021, 13, 1389. https://doi.org/10.3390/ su13031389

Academic Editor: Anna Visvizi

Received: 5 January 2021

Accepted: 24 January 2021

Published: 29 January 2021

Publisher's Note: MDPI stays neutral with regard to jurisdictional claims in published maps and institutional affiliations.

Copyright: (C) 2021 by the authors. Licensee MDPI, Basel, Switzerland. This article is an open access article distributed under the terms and conditions of the Creative Commons Attribution (CC BY) license (https:// creativecommons.org/licenses/by/ $4.0 /)$.

\begin{abstract}
This study examines the extent to which existing foreign direct investment (FDI) theories apply to Chinese investment in the Belt and Road Initiative (BRI) countries. This is important because existing explanations of Chinese outward FDI (OFDI) generally make scant reference to these theories. By using OFDI data for BRI countries between 2003 and 2017, we tested hypothesizes applicable to existing theories by using both pooled ordinary least squares (PLOS) and stochastic frontier analysis (SFA) methods. The results show that a large part of the existing theories apply to Chinese OFDI. Chinese OFDI is likely to choose countries with big market size, abundant natural resources, cheap unskilled labor, stable politics, good infrastructure, high trade cost and high investment cost. These positive findings notwithstanding, they do not invalidate the alternative factors cited by commentators which have not been subject to direct testing, which may require the use of qualitative analytical approaches.
\end{abstract}

Keywords: Chinese OFDI; FDI theory; BRI; Chinese multinational firms

\section{Introduction}

China's fast economic growth has relied on absorbing foreign direct investment (FDI) [1-3]. In 2009, China ranked second in the world in terms of inward foreign direct investment. However, since 2002, the Chinese government adopted its "go abroad" policy to encourage Chinese enterprises to invest in foreign countries. With China's growing economic strength, Chinese outward FDI (OFDI) began to rise sharply. From 2002 to 2018 , the average annual growth rate of China's OFDI reached 28.20\%. In 2012, China ranked among the top three source countries of foreign direct investment for the first time and maintained the position for the last few years. By the end of 2018, China had made investment in 43,000 overseas enterprises from 188 countries [4]. In the same year, China became the second largest source country for foreign direct investment for the third time [5].

In 2013, the Belt and Road Initiative (BRI) was launched as a Chinese grand strategy by Chinese President $\mathrm{Xi}$ Jinping to promote economic development and regional integration. The BRI is partly based on the Silk Road Economic Belt, which was proposed in September of 2013 when President Xi Jinping made a speech at Nazarbayev University, Kazakhstan. The Silk Road Economic Belt aims to build a land channel from the Pacific Ocean to the Baltic Sea by improving cross-border infrastructure and international trade and capital. Another component of the BRI is the 21st Century Maritime Silk Road which was proposed in October of 2013 when President Xi Jinping made a state visit to Indonesia and delivered a speech at the Indonesian Parliament. The 21st Century Maritime Silk Road not only connects China to the Association of Southeast Asian Nations (ASEAN) but also tries to link the countries together from the South China Sea to the Mediterranean Sea and the South Pacific Ocean. The BRI aims to establish and strengthen partnerships among the 
countries along the Belt and Road by policy coordination, facility connectivity, unimpeded trade, financial integration, and people-to-people bond.

After the launch of the BRI, OFDI stock increased significantly in BRI countries, from US $\$ 72.02$ billion in 2013 to US $\$ 154.40$ billion in 2017. China's rapid increase of the investment in BRI countries has aroused the interests of researchers, as most of the BRI countries are developing economies and the investment in BRI countries has its own characteristics. From the location distribution perspective, most of China's OFDI in BRI countries are concentrated in Asian countries, especially Southeast Asia countries. Intensive concentration is one of the characteristics of China's investment in BRI countries. Until 2017, out of the top 10 recipients of Chinese OFDI in BRI countries, 8 out of 10 were Asian countries (Singapore, Indonesia, Kazakhstan, Laos, Pakistan, Myanmar, Cambodia, and Thailand), and 6 out of 10 were from Southeast Asia countries (Singapore, Indonesia, Laos, Myanmar, Cambodia, and Thailand). From the sectoral distribution perspective, China's investment mainly targets energy, metals, and transport, which account for $68.56 \%$ of total industry distribution in BRI countries. Investment in energy sector is mostly merger and acquisition (M\&A) FDI, while the others are greenfield FDI. Energy subindustries such as oil, coal, gas, and hydro are the core drivers for BRI, which helps China to access reliable and efficient energy network. Except for the demand for traditional energy consumption, China is looking for environment-friendly energy such as gas from the Russian Federation and Kazakhstan, as environmental pollution is attracting more attention in the progress of economy development $[6,7]$.

With the development of BRI, the motivations behind BRI are being discussed extensively $[8,9]$. In the context of the "new normal" of slower growth of China's economy, it has been argued that the BRI is aimed to avoid the excess production capacity in the domestic market and secure natural resource supplies. Others have argued that the initiative promotes Chinese OFDI in infrastructure sectors by state-owned enterprises (SOEs) and non-infrastructure sectors by private enterprises [10]. What is striking about these motives is that they are primarily state priorities. Chinese SOEs as the main actors of Chinese government policies engage in overseas investment. When the Chinese government makes overseas investment policies from the national security, energy security, foreign policy, and geopolitics perspectives, Chinese SOEs will be pioneers to complete the tasks of the central government instead of considering the profitability and interests like the private enterprises. Meanwhile, the SOEs in China are easily financed by the government and banks; this results in Chinese overseas investment being high risk and even failing [11,12]. By contrast, existing theories explaining FDI are based on decision-making by privatesector firms. This leaves open the question of whether these theories can help explain Chinese OFDI.

China makes for an interesting study to test existing FDI theories given that it has several distinctive features. These are the central role of the state and its state enterprises, its being a major source of OFDI when most countries at a comparable level of development are focused on receiving inward FDI, and its OFDI flows to developed instead of developing countries [13,14].

This paper is arranged as follows. Section 2 reviews the existing general FDI theory and gives the hypothesis of motivations of Chinese investment in BRI countries. Section 3 describes the data source and the empirical strategy. Section 4 shows the results of regression analysis. The last section concludes the paper.

\section{Literature Review and Hypothesis Development}

FDI theories come almost exclusively from Western scholars and are based on enterprise behavior from developed countries [15]. The main objectives of FDI theory are internalizing imperfect markets and reducing operating costs. 


\subsection{Existing FDI Theory}

Hymer (1976) [16] explained the flows of FDI under the assumption that the market is imperfect. The imperfect market gives multinational enterprises (MNEs) a monopolistic advantage and the capacity to compete with local enterprises in host countries [17,18]. To compete with the local companies in host nations, an advantage should be owned by the international corporations to undertake investment abroad. The monopolistic advantage is a result of imperfect competition in goods and factor markets, economies of scale, and the obstacles from government [19].

Vernon's product life-cycle theory is used to explain why firms substitute foreign direct investment for exporting in the United States. Product life-cycle theory assumes that the flow of knowledge across regions or countries produces cost. The dynamic production of new products is a decision process between international trade and international investment [20]. It separates the product life cycle into three stages: innovation, maturity, and standardization. In the maturing product stage, threats from local industry rivals, foreign governments controlling imports, and lower labor costs in other countries force firms to undertake foreign direct investment. In the standardized product stage, less-developed countries have absolute advantage in labor. To keep a competitive advantage, firms invest in lower-cost countries. Labor-intensive products are transferred to developing countries for production first and later resold to a home country or other advanced countries.

The internalization theory can be tracked to the pioneering study by Coase (1937) [21], who tried to find the reasons for the emergence and for restricted growth of firms. Firm growth stops when the cost of organizing one more transaction within the firm equals the cost on the open market. Following Coase's theory, Buckley and Casson (1976) [22] explained the determinants and motivation of FDI in terms of firms' efforts to internalize transactions to reduce costs. Multinational enterprises make investment abroad when more benefits are acquired to have branches abroad than exporting, or when the costs of internalization are less than the costs of external transactions [23].

Dunning's eclectic paradigm claims that ownership, location, and internalization advantages are the main contributors of FDI. The ownership advantage, also known as monopolistic advantage, refers to the assets and ownership that a country's enterprises own or can acquire, which are not available to other enterprises. It mainly includes the asset ownership advantage and transactional ownership advantage [24]. The location advantage refers to the favorable conditions of foreign market relative to home market in terms of market environment for enterprise production and operation. It includes direct location advantage and indirect location advantage [25]. The internalization advantage refers to the ability of an enterprise to keep its advantages within the enterprise in order to avoid the influence of the incomplete external market on the enterprise interests [26].

Dunning (1981) [27] proposed the investment development path (IDP) theory, which is a dynamic approach to study the relationship between the development of an economy and foreign direct investment. The IDP theory assumes that with the development of the economy, the conditions for the domestic and foreign enterprises transform, which will finally affect the position of both inward and outward FDI [28] According to the theory, a country will experience five stages of development which result in the dynamic change of the ownership, location, and internalization advantages of enterprises. For stage 1 , as the domestic market is small and undeveloped, there is no inward FDI and OFDI. In stage 2, as the country has some location advantages, inward FDI flows into consumer goods and infrastructure sectors. There is no OFDI during this period. In stage 3 , with the growing of ownership advantages of domestic enterprises, overseas investment is increasing. In stage 4 , the country changes to a net OFDI position, as the advantages that enterprises have to manage the dispersed production are more important than the advantages that are based on the home country characteristics. In stage 5, the country has high stock of both inward and outward FDI. The empirical studies have tested the role of home country development, innovation, openness to trade and investment, and institutions $[1,29,30]$. As part of China's continuous government policies to support both inward and outward FDI, the stock of 
OFDI has surpassed inward FDI. According to the analysis in the introduction part, China's OFDI has the characteristics of stage 3.

Dunning's theory suggests that FDI is mainly characterized as market-seeking, assetseeking, and resource-seeking. With respect to the first objective, MNEs invest in foreign economics to sell goods and services there. Some firms feel that the best way to access those markets is by foreign direct investment [31]. Market-seeking investment focuses on sustaining or exploiting new markets. According to the eclectic paradigm and the IDP theory, market size of both home and host country and the prospect for market growth of host economic stimulate capital inflows from outbound [32]. The market size difference between home and host country has a negative effect on FDI flows, which means that horizontal foreign direct investment (HFDI) reaches a maximum value when the GDP of the home country and host country is equal and with similar relative endowments [33]. Thus, with specific reference to China:

Hypothesis 1 (H1). Chinese OFDI along BRI countries is correlated positively with absolute home country size.

Hypothesis 2 (H2). Chinese OFDI along BRI countries is correlated positively with absolute host country size.

Hypothesis 3 (H3). Chinese OFDI along BRI countries is correlated negatively with a difference between home and host country size.

When investors access frontier technologies and information by mergers and acquisitions (M\&A), they will upgrade their own high-tech production capabilities [34]. The motivation behind asset-seeking investment is to obtain advanced proprietary technology, high-skilled labor, brands, and distribution networks in local markets in order to strengthen a firm's own specific advantage or weaken its competitors [35-37]. To strengthen competitiveness, Chinese MNEs invest in advanced countries to access intellectual capital by M\&A, especially in the European Union (EU) and USA [38]. The measure of asset-seeking motivation is proxied by the rate of patenting or endowment of skilled labor in the host economies [39,40]. Thus:

Hypothesis 4 (H4). Chinese OFDI along BRI countries is correlated positively with host country endowments of technology.

Enterprises are also spurred to invest abroad to procure natural resources at a lower price than in the home country. Profit maximization is the main motivation for enterprises' investment of this kind. According to Dunning and Lundan (2008) [41], cheap and highly motivated unprofessional labor or primary labor is still the target of natural resourceseekers. This type of investment usually comes from the home country with higher labor costs than the host country. As China becomes the world factory since joining the World Trade Organization (WTO) in 2001, its position changes from one of a net oil exporter to a net oil importer [42]. Chinese investment in Africa mainly focuses on natural resources. Chinese enterprises even invest in advanced countries such as Australia to achieve the efficient mining sector in order to guarantee the demand of the energy in the home market $[43,44]$. Thus:

Hypothesis 5 (H5). Chinese OFDI along BRI countries is correlated positively with host country endowments of natural resources.

Beyond these motivating factors are others suggested by empirical studies. They include:

\subsubsection{Geographic Distance}

Geography distance affects location choice of MNEs by increasing investment costs [45]. Thus: 
Hypothesis 6 (H6). Chinese OFDI along BRI countries is correlated negatively with host country increasing physical distance.

\subsubsection{Political Risk}

Political risk refers to the risk that a host country government changes the rule of a business game with no advance notice. The higher the risk, the less likely the chance of a favorable FDI decision [46]. Thus:

Hypothesis 7 (H7). Chinese OFDI along BRI countries is correlated negatively with host country increasing political risk.

\subsubsection{Trade Cost}

Trade and foreign direct investment are trade-off relationships [47]. MNEs will choose the strategy of foreign direct investment if the cost of exporting to overseas and producing in the home market is more than the cost of operating and producing in the home market plus the cost of importing to the home country [48]. Thus:

Hypothesis 8 (H8). Chinese OFDI along BRI countries is correlated positively with host country trade cost.

Hypothesis 9 (H9). Chinese OFDI along BRI countries is correlated negatively with home country trade cost.

\subsubsection{Investment Cost}

Investment cost refers to the cost of doing foreign business in a host country. The higher the investment cost, the less likely it is for FDI [49]. Thus:

Hypothesis 10 (H10). Chinese OFDI along BRI countries is correlated negatively with investment cost in host country.

\subsubsection{Infrastructure}

Infrastructure is one of the key determinants of foreign investment [50,51]. The relationship between infrastructure and foreign investment is usually positive. Countries with good quality infrastructure will attract more investment inflows as it increases the accessibility and decreases the transport cost. Thus:

Hypothesis 11 (H11). Chinese OFDI along BRI countries is correlated positively with physical infrastructure in a host country.

\subsubsection{Government Effectiveness}

Government effectiveness captures the capacity for the government to provide public services. Good governance in a host country matters for foreign direct investment, and it insures the favorable environment of business. Government effectiveness ensures the consistence of implementing foreign investment policy, and enhances the confidence of foreign investors [52-54]. Thus:

Hypothesis 12 (H12). Chinese OFDI along BRI countries is correlated positively with government effectiveness in a host country.

\section{The Model and Data}

To assess the determinants of Chinese investment in BRI countries, both pooled ordinary least squares (PLOS) and stochastic frontier analysis (SFA) are used $[55,56]$.

Based on Carr et al. (2001) [32], the specific model used is as follows: 


$$
\begin{gathered}
F D I_{i j}^{t}=\beta_{0}+\beta_{1} G D P_{i}^{t}+\beta_{2} G D P_{j}^{t}+\beta_{3} S Q D G D P_{i j}^{t}+\beta_{4} D I S_{i j}+\beta_{5} D S K I L L_{i j}^{t}+ \\
\beta_{6} R E S O U R C E_{i}^{t}+\beta_{7}\left(D G D P_{i j}^{t} \times D S K I L L_{i j}^{t}\right)+v_{i j}^{t}-u_{i j}^{t}
\end{gathered}
$$

where

$$
\begin{aligned}
& u_{i j}^{t}=\alpha_{0}+\alpha_{1} \text { TRADECOST } T_{i}^{t}+\alpha_{2} \text { TRADECOST } T_{j}^{t}+\alpha_{3} \operatorname{INVCOST}_{j}^{t}+\alpha_{4} I N F R A_{j}^{t} \\
& +\beta_{5} \text { GOVERNMENT } T_{j}^{t}+\beta_{6} \text { POLITICAL } L_{j}^{t}+w_{i j}^{t}
\end{aligned}
$$

where

$i=$ home country

$j=$ host country

$F D I_{i j}^{t}$ represents the outward foreign direct investment from China to countries along the BRI (Table 1). The accumulative volume of OFDI is used as the dependent variable [57]. The data are from 2003 to 2017 and come from the various years of Statistical Bulletin of China's Outward Foreign Direct Investment.

Table 1. Countries along One Belt One Road.

\begin{tabular}{ll}
\hline \multicolumn{1}{c}{ Region } & \multicolumn{1}{c}{ Country } \\
\hline East Asia (2) & China (CHN), Mongolia (MNG) \\
\hline \multirow{2}{*}{ Southeast Asia (11) } & Brunei (BRN), Cambodia (KHM), Indonesia (IDN), \\
& Laos (LAO), Malaysia (MYS), Myanmar (MMR), \\
& Philippines (PHL), Singapore (SGP), Thailand (THA), \\
& Timor-Leste (TLS), Vietnam (VNM) \\
\hline \multirow{2}{*}{ Central Asia (5) } & Kazakhstan (KAZ), Kyrgyzstan (KGZ), Tajikistan (TJK), \\
& Turkmenistan (TKM), Uzbekistan (UZB) \\
\hline \multirow{3}{*}{ Middle East and North Africa (15) } & Bahrain (BHR), Egypt (EGY), Iran (IRN), \\
& Iraq (IRQ), Israel (ISR), Jordan (JOR), \\
& Kuwait (KWT), Lebanon (LBN), Oman (OMN), \\
& Palestine (PSE), Qatar (QAT), Saudi Arabia (SAU), \\
& Syria (SYR), United Arab Emirates (ARE), Yemen (YEM) \\
South Asia (8) & Afghanistan (AFG), Bangladesh (BGD), Bhutan (BTN), \\
& India (IND), Maldives (MDV), Nepal (NPL), \\
& Pakistan (PAK), Sri Lanka (LKA) \\
\hline & Albania (ALB), Armenia (ARM), Azerbaijan (AZE), \\
& Belarus (BLR), Bosnia and Herzegovina (BIH), Bulgaria (BGR), \\
& Croatia (HRV), Czech Republic (CZE), Estonia (EST), \\
& Georgia (GEO), Hungary (HUN), Latvia (LVA), \\
Europe (24) & Lithuania (LTU), Macedonia (MKD), Moldova (MDA), \\
& Montenegro (MNE), Poland (POL), Romania (ROU), \\
& Russia (RUS), Serbia (SRB), Slovakia (SVK), \\
& Slovenia (SVN), Turkey (TUR), Ukraine (UKR) \\
\end{tabular}

$G D P_{i}^{t}$ and GDP $P_{j}^{t}$ denote the home country GDP and host country GDP in a given year $\mathrm{t}$, respectively. The data come from the World Bank's World Development Indicators. A positive correlation is expected for both variables.

$S Q D G D P_{i j}^{t}$ is squared difference of GDP between home country and host country. It is used to test the similarity of market size. According to Carr et al. (2001) [32], when the similarity of market size is close to zero, foreign direct investment reaches the maximum. The correlation is expected to be negative.

$D I S_{i j}$ is the physical distance between home country capital city and host country capital city. Increasing physical distance increases the transport cost and decreases the flow 
of foreign investment [58]. Measured in kilometers, the data are accessible from the Centre for International Prospective Studies and Information (CEPII).

$D S K I L L_{i j}^{t}$ measures the skill difference between home country and host country in year t. According to Voss (2011) [59], percentage ratio of enrolment in tertiary education is used to represent the skill level of a home country. The data come from the World Bank's World Development Indicators. The positive relationship between skill and FDI is expected.

RESOURCE $E_{i}^{t}$ equals the home country demand of natural resources in a given year t. China's import of energy represents its natural resources-seeking behavior [60]. The data are from various years of the China Statistic Yearbook. A positive relationship between natural resources and FDI is expected.

$D G D P_{i j}^{t} \times D S K I L L_{i j}^{t}$ is an interaction term between the difference of market size and skill difference. When a home country is relatively small and has abundant skilled labor, foreign investment is the highest [32]. Thus, correlation is expected to be negative.

INFR $A_{j}^{t}$ represents the infrastructure in the host country. Available from the World Bank's World Development Indicators, water, electric power, railway, internet, mobile cellular, and airport are all included to measure the infrastructure with the same weight. Thus, the correlation is expected to be positive.

TRADECOST $T_{i}^{t}$ and TRADECOST $T_{j}^{t}$ represent the trade cost of home country and host country in year $t$, respectively. Because of data limitations, we calculate the trade cost indirectly by 100 minus trade freedom. The trade freedom index is a composite measure of the tariff and nontariff barriers that affect the cost of international trade. Nontariff barriers include quantity restrictions, price restrictions, regulatory restriction, customs restriction, and direct government intervention. The value ranges from 0 to 100 . The trade freedom data come from the Index of Economic Freedom released by the Heritage Foundation. We expect a negative sign for trade cost of home country and a positive sign for trade cost of host country [61].

$I N V C O S T_{j}^{t}$ means the investment cost in the host country in a given year $t$. Because of data limitations, we calculate the investment cost indirectly by 100 minus the index of investment freedom. The investment freedom index includes the national treatment of foreign investment, foreign investment code, restrictions on land ownership, sectoral investment restrictions, foreign exchange controls, and capital controls. This value ranges from 0 to 100. The index also comes from the Index of Economic Freedom released by the Heritage Foundation. A negative sign is expected for the relationship between investment cost and FDI.

GOVERNMENT $T_{j}^{t}$ refers to government effectiveness of the host country in a given year $t$. Greater government effectiveness helps foreign companies invest in the local market [62]. The data are available from the World Bank's World Development Indicators. A positive correlation is expected for both variables.

POLITICAL $t_{j}^{t}$ measures the political stability of the host country. It measures perceptions of the likelihood of political instability and/or politically motivated violence, including terrorism. The data are from the World Bank's Governance Indicators. The correlation is expected to be negative.

\section{Results and Discussion}

Descriptive statistics of the data are summarized in Table 2. All variables are expressed in natural logs except the data from the Index of Economic Freedom and Governance Indicators (trade cost, investment cost, government, and political stability). 
Table 2. Descriptive Analysis of the Data for SFA Model.

\begin{tabular}{|c|c|c|c|c|c|}
\hline Variable & Obs & Mean & Std. Dev. & Min & Max \\
\hline$F D I_{i j}^{t}$ & 896 & 3.89 & 2.92 & -4.61 & 10.70 \\
\hline$G D P_{i}^{t}$ & 960 & 29.39 & 0.39 & 28.70 & 29.95 \\
\hline$G D P_{j}^{t}$ & 949 & 24.64 & 1.64 & 20.60 & 28.60 \\
\hline$S Q D G D P_{i j}^{t}$ & 948 & 16.17 & 2.88 & 3.11 & 22.64 \\
\hline$D I S_{i j}$ & 960 & 8.57 & 0.38 & 7.07 & 8.95 \\
\hline RESOURCE $E_{i}^{t}$ & 780 & 2.05 & 1.65 & -9.54 & 17.50 \\
\hline Enroll $_{j}^{t}$ & 873 & 3.35 & 0.82 & -1.64 & 4.56 \\
\hline$D S K I L L_{i j}^{t}$ & 868 & 0.70 & 1.10 & $5.76 \times 10^{-7}$ & 19.04 \\
\hline$D G D P_{i j}^{t} \times D S K I L L_{i j}^{t}$ & 858 & -2150.52 & 9594.97 & $-99,192.33$ & $29,651.07$ \\
\hline$T R A D E C O S T_{i}^{t}$ & 960 & 32.57 & 7.83 & 26.40 & 49.40 \\
\hline TRADECOST $T_{j}^{t}$ & 862 & 25.52 & 12.86 & 10.00 & 100.00 \\
\hline$I N V C O S T_{j}^{t}$ & 863 & 51.58 & 21.35 & 10.00 & 100.00 \\
\hline POLITICAL $L_{j}^{t}$ & 927 & 40.68 & 27.76 & 0.00 & 119.31 \\
\hline $\operatorname{INFR} A_{j}^{t}$ & 960 & 12.05 & 3.10 & -1.84 & 16.96 \\
\hline GOVERNMENT $T_{j}^{t}$ & 928 & 0.03 & 0.83 & -1.84 & 2.44 \\
\hline
\end{tabular}

Notes: 1. All variables are in natural logs except TRADECOST $t_{i}^{t}, T R A D E C O S T_{j}^{t}, I N V C O S T_{j}^{t}$, GOVERNMENT $_{j}^{t}$, and POLITICAL P $_{j}^{t}$. For the definition of each variable and its source, refer to Appendix A.

For the market size variable, the mean of China's GDP is higher than that of BRI countries as a whole. Most of the BRI states are developing economies, and their market sizes are relatively small, which means that China's enterprises have advantages in competition and technology over those of enterprises from BRI countries.

For trade cost, the mean of BRI countries' trade cost is lower than that of China. The relatively low trade cost gives the host country strong trade efficiency that will attract more direct investment from overseas. Also, the benefit of producing outside the home country outweighs the loss of economies of scale compared to merely concentrating on production in the home market.

The Pearson Correlation matrix is shown in Table 3. China's outward FDI has a strong relationship with the GDP of the host country, which is 0.48 . The relationship between China's outward FDI and infrastructure of the host country is the same as above. The strongest negative relationship is -0.84 between the GDP of the home country and the investment cost of the home country. Although this value means that the two variables are highly correlated as the value is above 0.8 , the variance inflation factor (VIF) test shows that all VIF values are below 5 (Table 4). The VIF test shows that the multicollinearity problem does not exist. 
Table 3. Correlation Matrix for All Variables.

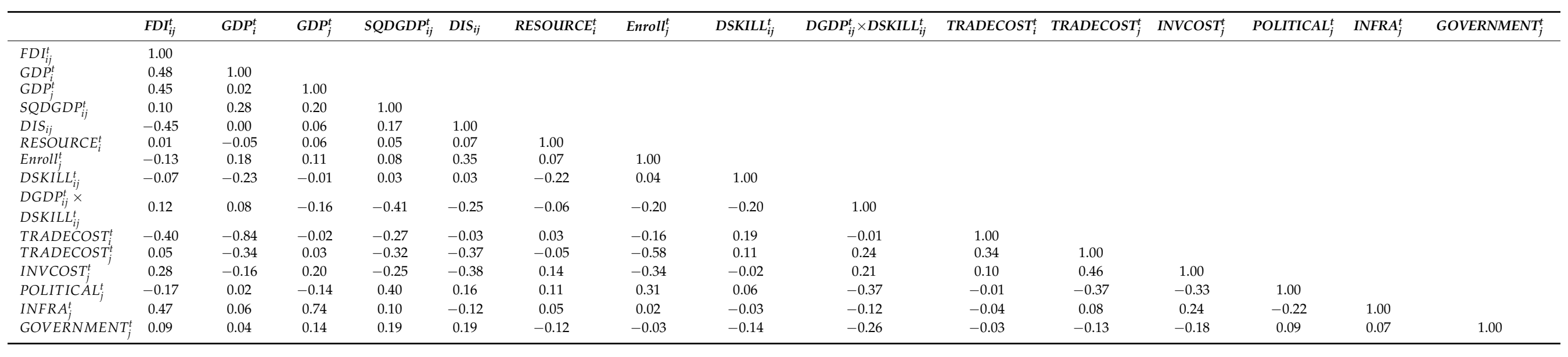


Table 4. Variance Inflation Factor (VIF) Test.

\begin{tabular}{|c|c|c|}
\hline Variable & VIF & 1/VIF \\
\hline$G D P_{j}^{t}$ & 3.85 & 0.26 \\
\hline$G D P_{j}^{t}$ & 2.59 & 0.39 \\
\hline$S Q D G D P_{i j}^{t}$ & 1.75 & 0.57 \\
\hline$D I S_{i j}$ & 1.44 & 0.69 \\
\hline RESOURCE $E_{i}^{t}$ & 1.20 & 0.84 \\
\hline Enroll $_{j}^{t}$ & 1.88 & 0.53 \\
\hline$D S K I L L_{i j}^{t}$ & 1.27 & 0.79 \\
\hline$D G D P_{i j}^{t} \times D S K I L L_{i j}^{t}$ & 1.58 & 0.63 \\
\hline TRADECOST & 3.57 & 0.28 \\
\hline TRADECOST $T_{j}^{t}$ & 2.14 & 0.47 \\
\hline$I N V \operatorname{COST} T_{j}^{t}$ & 1.65 & 0.61 \\
\hline POLITICAL $L_{j}^{t}$ & 1.66 & 0.60 \\
\hline$I N F R A_{j}^{t}$ & 2.50 & 0.40 \\
\hline GOVERNMENT & 1.26 & 0.80 \\
\hline
\end{tabular}

\section{Empirical Findings for BRI Countries}

The empirical findings of the stochastic frontier analysis (SFA) of China's OFDI along BRI countries are shown in Table 5. According to the characteristic of the SFA model, before doing an SFA analysis, the skewness and kurtosis test [63] is used to test the negative skewness of the OLS residuals, in order to reject the null hypothesis of zero skewness in the errors and to check whether the stochastic frontier analysis is suitable for analysis.

Table 5. A Stochastic Frontier Specification of China's OFDI along BRI Countries.

\begin{tabular}{|c|c|c|c|c|c|c|}
\hline & 1 & 2 & 3 & 4 & 5 & 6 \\
\hline \multicolumn{7}{|c|}{ Frontier Determinants } \\
\hline$G D P_{i}^{t}$ & $3.50 * * *(0.25)$ & $3.56^{* * *}(0.26)$ & $3.64^{* * *}(0.26)$ & $3.77^{* * *}(0.29)$ & $3.82^{* * *}(0.25)$ & $4.01^{* * *}(0.24)$ \\
\hline$G D P_{j}^{t}$ & $0.95^{* * *}(0.05)$ & $0.97^{* * *}(0.04)$ & $0.94^{* * *}(0.05)$ & $0.95^{* * *}(0.05)$ & $0.87^{* * *}(0.06)$ & $0.75^{* * *}(0.07)$ \\
\hline$S Q D G D P_{i j}^{t}$ & $-0.09^{* * *}(0.03)$ & $-0.09^{* *}(0.03)$ & $-0.07^{* *}(0.03)$ & $-0.09^{* * *}(0.03)$ & $-0.09^{* * *}(0.03)$ & $-0.09^{* * *}(0.03)$ \\
\hline$D I S_{i j}$ & $-3.27^{* * *}(0.19)$ & $-3.33^{* * *}(0.19)$ & $-3.24^{* * *}(0.19)$ & $-3.30^{* * *}(0.19)$ & $-3.16^{* * *}(0.20)$ & $-3.14^{* * *}(0.21)$ \\
\hline RESOURCE $E_{i}^{t}$ & $0.12^{* * *}(0.04)$ & $0.12^{* *}(0.04)$ & $0.10^{* *}(0.04)$ & $0.10^{* *}(0.04)$ & $0.12^{* * *}(0.04)$ & $0.15^{* *}(0.04)$ \\
\hline Enroll $_{j}^{t}$ & $-0.59^{* * *}(0.10)$ & $-0.74^{* * *}(0.12)$ & $-0.69^{* * *}(0.12)$ & $-0.76^{* * *}(0.12)$ & $-0.74^{* * *}(0.12)$ & $-0.58^{* * *}(0.12)$ \\
\hline$D S K I L L_{i j}^{t}$ & $0.39^{* * *}(0.11)$ & $0.44^{* * *}(0.12)$ & $0.42^{* * *}(0.12)$ & $0.40^{* * *}(0.12)$ & $0.41^{* * *}(0.12)$ & $0.57^{* * *}(0.13)$ \\
\hline $\begin{array}{l}D G D P_{i j}^{t} \times \\
D S K I L L_{i j}^{t}\end{array}$ & $\begin{array}{c}0.00001(7.46 \times \\
\left.10^{-6}\right)\end{array}$ & $\begin{array}{l}0.00001 *(7.56 \\
\left.\quad \times 10^{-6}\right)\end{array}$ & $\begin{array}{l}0.00001 *(7.52 \\
\left.\quad \times 10^{-6}\right)\end{array}$ & $\begin{array}{l}0.00001 *(7.42 \\
\left.\quad \times 10^{-6}\right)\end{array}$ & $\begin{array}{l}0.00001 *(7.41 \\
\left.\quad \times 10^{-6}\right)\end{array}$ & $\begin{array}{c}0.00002^{* * *}(6.79 \\
\left.\times 10^{-6}\right)\end{array}$ \\
\hline Intercept & $\begin{array}{l}-89.99 * * * \\
(7.31)\end{array}$ & $\begin{array}{c}-91.67^{* * *} \\
(7.58)\end{array}$ & $\begin{array}{c}-94.20^{* * *} \\
(7.68)\end{array}$ & $\begin{array}{c}-97.72 * * * \\
(7.82)\end{array}$ & $\begin{array}{c}-97.84^{* * *} \\
(7.53)\end{array}$ & $\begin{array}{c}-101.19 * * * \\
(7.11)\end{array}$ \\
\hline \multicolumn{7}{|c|}{ Inefficiency Determinants } \\
\hline TRADECOST $t_{i}^{t}$ & $0.04^{* * *}(0.01)$ & $0.04 *(0.02)$ & $0.03(0.02)$ & $0.03(0.02)$ & $0.02(0.01)$ & $0.01(0.01)$ \\
\hline$T R A D E C O S T_{j}^{t}$ & & $0.03^{* * *}(0.01)$ & $0.03^{* * *}(0.01)$ & $0.03^{* * *}(0.01)$ & $0.03^{* * *}(0.01)$ & $0.02^{* * *}(0.01)$ \\
\hline$I N V \operatorname{COST} T_{j}^{t}$ & & & $-0.01^{* * *}(0.01)$ & $-0.01^{* *}(0.01)$ & $-0.01^{* *}(0.01)$ & $-0.02^{* * *}(0.01)$ \\
\hline POLITICAL $L_{j}^{t}$ & & & & $-0.01 *(0.01)$ & $-0.01^{* *}(0.004)$ & $-0.01 * *(0.004)$ \\
\hline$I N F R A_{j}^{t}$ & & & & & $-0.12 * *(0.05)$ & $-0.16^{* * *}(0.05)$ \\
\hline GOVERNMENT $T_{j}^{t}$ & & & & & & $-0.61^{* * *}(0.12)$ \\
\hline No. of obs & 662 & 621 & 621 & 607 & 607 & 593 \\
\hline
\end{tabular}

Notes: $1 . * * * *$, and ${ }^{*}$ denote the significance at the $1 \%, 5 \%$, and $10 \%$ levels. 2 . For the definition of each variable, refer to Appendix A. 3 . Standard Errors Are Reported in Parentheses. 
As seen in Table 6 , all residuals have negative skewness at the $5 \%$ or $1 \%$ levels proving that the SFA model is suitable for this data analysis. Meanwhile, the Chi-square statistics [64] reject the null hypothesis of constant variance of errors, and thus provide evidence of technical inefficiency in the independent variables. The non-constant variance of errors also means that heteroscedasticity exists, which will lead to serious problems in the estimation of the Maximum Likelihood (ML) parameters [65].

Table 6. Skewness and Variance Tests based on China's OFDI along BRI Countries.

\begin{tabular}{|c|c|c|c|c|}
\hline & 1 & 2 & 3 & 4 \\
\hline$G D P_{i}^{t}$ & $3.47^{* * *}(0.18)$ & $3.85^{* * *}(0.19)$ & $4.06^{* * *}(0.19)$ & $4.03^{* * *}(0.20)$ \\
\hline$G D P_{j}^{t}$ & $0.97^{* * *}(0.04)$ & $0.96^{* * *}(0.04)$ & $0.96^{* * *}(0.04)$ & $0.97^{* * *}(0.04)$ \\
\hline$S Q D G D P_{i j}^{t}$ & $-0.05^{* *}(0.02)$ & $-0.10^{* * *}(0.03)$ & $-0.11^{* * *}(0.03)$ & $-0.10^{* * *}(0.03)$ \\
\hline$D I S_{i j}$ & $-3.79 * * *(0.18)$ & $-3.25^{* * *}(0.19)$ & $-3.27^{* * *}(0.19)$ & $-3.25^{* * *}(0.19)$ \\
\hline RESOURCE $E_{i}^{t}$ & $0.08 *(0.04)$ & $0.08^{* *}(0.04)$ & $0.13 *(0.04)$ & $0.13^{* * *}(0.04)$ \\
\hline Enroll $_{j}^{t}$ & & $-0.55^{* * *}(0.10)$ & $-0.55^{* * *}(0.10)$ & $-0.54^{* * *}(0.10)$ \\
\hline$D S K I L L_{i j}^{t}$ & & & $0.44^{* * *}(0.11)$ & $0.45^{* * *}(0.11)$ \\
\hline$D G D P_{i j}^{t} \times D S K I L L_{i j}^{t}$ & & & & $5.39 \times 10^{-6}\left(7.99 \times 10^{-6}\right)$ \\
\hline Intercept & $-88.95^{* * *}(5.44)$ & $-102.01^{* * *}(5.84)$ & $-108.31^{* * *}(5.99)$ & $-107.85^{* * *}(6.03)$ \\
\hline No. of obs & 726 & 666 & 662 & 662 \\
\hline R square & 0.65 & 0.66 & 0.67 & 0.67 \\
\hline Skewness & $-0.20^{* *}$ & $-0.37^{* * *}$ & $-0.29^{* * *}$ & $-0.30^{* * *}$ \\
\hline Chi square & $8.51^{* * *}$ & $7.23^{* * *}$ & $10.81^{* * *}$ & $10.79 * * *$ \\
\hline
\end{tabular}

Notes: $1 .{ }^{* * *}, * *$, and ${ }^{*}$ denote the significance at the $1 \%, 5 \%$, and $10 \%$ levels. 2 . For the definition of each variable, refer to Appendix A. 3. Standard Errors are reported in parentheses.

Table 5 presents the single-step ML estimates for the two-equation stochastic frontier specification (Equations (1) and (2)). In columns 1 to 3, the OFDI inefficiency is represented by the cost variables, while columns 4 to 6 increasingly augment a set of technical efficiency effects with extra OFDI-related variables.

The results of the SFA model show that the market size of both home country and host country are significant at the $1 \%$ level and with correct relationship. The GDP of the home country has a positive influence on China's OFDI (Hypothesis 1), with a $1 \%$ increase in the variable increasing China's OFDI by $4.01 \%$. Although, the host country's GDP has a positive influence on China's OFDI (Hypothesis 2), the effect is limited and a $1 \%$ rise in the variable will increase China's OFDI by only $0.75 \%$. As stated before, China's GDP is bigger than the BRI countries; with a 1\% increase of GDP, the home market's GDP has more influence on China's OFDI than the host market's GDP.

The difference between the home country's market size and the host country's market size has a strong negative effect on the OFDI from China on the $1 \%$ level, which means that China's investment mainly flows to the host country with similar GDP (Hypothesis 3).

For asset-seeking motivation, the correlation between the skill and China's OFDI is strongly negative at the $1 \%$ level, which means that China's OFDI seeks the country that has a low technology level. This result is opposite to Hypothesis 4, which has been proven by other studies $[66,67]$. As this study is focused on the countries along the BRI, the Chinese government is the major player of promoting OFDI. The investment in BRI countries is mainly contributed by SOEs or private enterprises with a close relationship with the Chinese government [68]. FDI is mainly concentrated in the manufacturing, energy, and infrastructure sectors with Chinese enterprises usually bringing the management team and skilled workers from China to a host country. Finally, it reduces the employment of skilled workers from the host country. Meanwhile, as the labor cost increases in China in 
recent years, some labor-intensive industries have transferred their production from China to countries with lower labor costs [69].

China's OFDI is motivated by natural resources needs [70,71]. The analysis shows a strong positive relationship between natural resources and China's OFDI at the $1 \%$ level, which means a $1 \%$ rise in the variable, increasing China's outward investment by $0.15 \%$, and the result confirms Hypothesis 5.

The distance between the home country and the host country has a significant negative effect on China's OFDI. With a $1 \%$ increase in distance, China's OFDI decreases by $3.14 \%$, which confirms Hypothesis 6. China's OFDI focuses on countries near home and that have a good relationship with the Chinese government.

The technology difference between China and the host country has a significant positive relationship with China's OFDI at the $1 \%$ level. This means that most of the OFDI from China flows into the country that has lower technology than China. Infrastructure development is one of the crucial aims of the BRI, so that investment from China to BRI countries is not technology-seeking.

The interaction term between the difference in GDP and skill has a significant positive relationship with the dependent variable. Although its influence on China's OFDI is small, with a $1 \%$ rise in the variable increasing only $0.00002 \%$ of China's OFDI, its influence is significant at the $1 \%$ level. Contrast this to the expectation that China's OFDI is likely to choose the country with big market size and low-skilled workers. For the country with abundant low-skilled workers, the difference in GDP has a positive effect on attracting Chinese investment although the home country's market size is small, which means that market-seeking is not the goal of Chinese investment.

According to the characteristics of the SFA model, the inefficient elements should be signed oppositely to the conventional determinates of OFDI. Specifically, the home country's trade cost, host country's trade cost, and host country's investment should be associated with positive, negative, and positive signs in SFA model, respectively. For the other inefficient elements such as political risks, infrastructure, and government, the correlations should be positive, negative, and negative (Table 7).

Table 7. Summary of the SFA Results.

\begin{tabular}{|c|c|c|}
\hline & Real Sign & Expected Sign \\
\hline$G D P_{i}^{t}$ & + & + \\
\hline$G D P_{j}^{t}$ & + & + \\
\hline$S Q D G D P_{i j}^{t}$ & - & - \\
\hline$D I S_{i j}$ & - & - \\
\hline RESOURCE $E_{i}^{t}$ & + & + \\
\hline Enroll $_{j}^{t}$ & - & + \\
\hline$D S K I L L_{i j}^{t}$ & + & + \\
\hline$D G D P_{i j}^{t} \times D S K I L L_{i j}^{t}$ & + & - \\
\hline$T R A D E C O S T_{i}^{t}$ & NS & + \\
\hline$T R A D E C O S T_{j}^{t}$ & + & - \\
\hline$I N V \operatorname{COST} T_{j}^{t}$ & - & + \\
\hline POLITICAL $L_{j}^{t}$ & - & + \\
\hline$I N F R A_{j}^{t}$ & - & - \\
\hline GOVERNMENT $_{j}^{t}$ & - & - \\
\hline
\end{tabular}

For the political variable, there is a significant negative relationship between the political stability of the host country and that of China's outward investment at the $5 \%$ level. This proves Hypothesis 7. This means that China's investment is trying to find the country with relatively stable politics.

With regard to trade cost for both the home country and host country (Hypothesis 8 and 9), the results show that there is no evidence to prove that the home country's trade cost 
has any significant relationship with the home country's OFDI except in SFA interpretation in columns 1 and 2. The trade cost of the host country has a significant negative strong relationship with China's OFDI at the $1 \%$ level; the correlation sign is opposite to our Hypothesis 8. One of the reasons is that, as for the vertical foreign direct investment (VFDI), the home country usually sets the plant in the host country and the headquarters in the home market, the products are re-imported to the home country after finishing the production in the host country [72,73]. In this case, the VFDI is mainly decided by the trade cost of both home country and host country. In this study, the home country's trade cost has no effect on the flow of China's investment; the only determinate is the host country's trade cost (Hypothesis 9). When the trade cost of the host country increases, the VFDI decreases.

For the investment cost of the host country, the result shows the opposite sign to Hypothesis 10. Normally, the investment cost of the host country has a negative influence on the OFDI from the home country. In the SFA model, the results are significant at the $1 \%$ level but with the opposite signs. This means that China's investment along the BRI countries tend toward the markets with high investment cost.

With regard to infrastructure, there is still a significant negative relationship between the infrastructure of the host country and China's OFDI at the 1\% level. Hypothesis 11 has therefore been confirmed. The same conclusion applies to government efficiency. The results show that China's investment is mainly focuses on the host country that has a relative better infrastructure and higher government efficiency.

\section{Conclusions}

Chinese investments in BRI countries over the period of 2003-2017 have been tested against hypotheses from existing FDI theories by using both OLS and SFA methods. These tests show that the market size of BRI countries does matter for China's OFDI, which seeks to remove excess capacity in the production of construction and other materials in China [74]. This proactive FDI strategy releases the stress of excess capacity in China's manufacturing industry, such as steel production. From the firm level, this strategy enlarges the market size and makes profits for the firm. At the country level, the core interest behind China's proactive FDI strategy is to maintain the rate of economic growth despite excess production. Natural resources also have a significant positive effect on Chinese investment in this area. As the world's factory, China consumes more natural resources to produce the products that will be sold to all over the world. Meanwhile, to satisfy the desire for domestic consumption, there is a huge demand for natural resources. All of the above contributes to the natural resources-seeking FDI, which becomes more significant than market-seeking FDI in BRI countries. Especially, for the countries that have rich natural resources and a good relationship with China.

In contrast to analysis that asset-seeking is one of the motivations for FDI from China [75], China's investment in BRI is not motivated by asset-seeking but by low-cost labor in host countries. In other words, China is transferring its labor-intensive industry to BRI countries because of the increasing labor cost in China [76,77]. The negative effect of geographic distance also shows that the vertical foreign direct investment is the main type of Chinese OFDI. All in all, this new phenomenon indicates that China's investment in BRI countries is more like the "North to South" investment. China is acting the role of "developed country" to invest to less-developed countries to seek markets, natural resources, and cheap labor.

Contradicting De Soyres, Mulabdic, Murray, Rocha, and Ruta (2019) [78], trade cost and investment cost of host countries have negative effects on attracting Chinese investment. Chinese investment prefers to flow to the countries with unstable politics. These contradictory results hint at Chinese OFDI behaving somewhat differently from the traditional FDI of private enterprises [79]. This difference is the result of Chinese government policy which aims to promote the investment in BRI countries mainly from the perspective of state interests. The state interests consider both the economic element and the strategical element. Normally, the stated-owned enterprises (SOE) will act as the agent of government 
to fulfill the strategical aim, while the economic aim is fulfilled by private enterprises. When we focus exclusively on an economic perspective, the strategic element will not fit.

Yet, the above results show existing theory to be able to explain a large part of Chinese OFDI in BRI countries. However, there are some limitations of this research. As Chinese government issues all kinds of polices to promote OFDI in BRI countries, it is still unavailable to use the quantitative method to test the role of government policies. As for the data limitation, there is no comprehensive firm level data to exam the motivation difference between the SOEs and private enterprises. Further, the case study will be used to test the role of government policies in the way of encouraging enterprises to make investments overseas. In specific, the interaction between government policy and enterprises (SOEs and private enterprises) will be explained by using document review and interviews.

Author Contributions: Conceptualization, L.C. and K.-C.C.; data curation, J.L.; funding acquisition, J.L.; methodology, L.C.; supervision, K.-C.C. and L.-T.G.; writing-original draft, L.C. and K.-C.C. All authors have read and agreed to the published version of the manuscript.

Funding: This study was financially supported by the National Natural Science Foundation of China (No. 51803096), the Open Project Program of Key Laboratory of Eco-textiles, Ministry of Education, Jiangnan University (No. KLET2004), the Fundamental Research Funds for the Provincial Universities of Zhejiang (No. SJWY2021015), Ningbo Science and Technology Bureau/Natural Science Foundation Project (No. 202003N4076), and K.C. Wong Mangna Fund in Ningbo University.

Acknowledgments: We thank the anonymous reviewers for their careful reading of our manuscript and their many insightful comments and suggestions.

Conflicts of Interest: The authors declare no conflict of interest.

\section{Appendix A}

Table A1. Variable Description.

\begin{tabular}{|c|c|c|c|}
\hline Variable & Description & Expected Sign & Data Source \\
\hline \multicolumn{4}{|c|}{ Dependent Variable } \\
\hline$F D I_{i j t}$ & $\begin{array}{l}\text { The log of OFDI stock of } \\
\text { China in country } j\end{array}$ & & $\begin{array}{l}\text { Statistical Bulletin of China's } \\
\text { Outward Foreign Direct } \\
\text { Investment }\end{array}$ \\
\hline \multicolumn{4}{|c|}{ Frontier Determinants } \\
\hline$G D P_{i t}$ & $\begin{array}{l}\text { The log of GDP for the home } \\
\text { country }\end{array}$ & $(+)$ & $\begin{array}{l}\text { World Development } \\
\text { Indicators }\end{array}$ \\
\hline$G D P_{j t}$ & $\begin{array}{l}\text { The log of GDP for the host } \\
\text { country }\end{array}$ & $(+)$ & $\begin{array}{l}\text { World Development } \\
\text { Indicators }\end{array}$ \\
\hline$D G D P S Q_{i j t}$ & $\begin{array}{l}\text { The square of the difference } \\
\text { between the log of the two } \\
\text { countries' GDP: }\end{array}$ & $(-)$ & $\begin{array}{l}\text { World Development } \\
\text { Indicators }\end{array}$ \\
\hline$D I S_{i j}$ & $\begin{array}{l}\text { The log of the great circle } \\
\text { distance between the capital } \\
\text { cities of two countries }\end{array}$ & $(-)$ & CEPII \\
\hline$D_{S K I L} L_{i j t}$ & $\begin{array}{l}\text { The difference between the } \\
\text { log of the two countries' skills } \\
\text { level, measured by the ratio of } \\
\text { enrolment in tertiary } \\
\text { education }\end{array}$ & $(+)$ & $\begin{array}{l}\text { World Development } \\
\text { Indicators }\end{array}$ \\
\hline RESOURCE $E_{i t}$ & $\begin{array}{l}\text { The log of the import of } \\
\text { energy }\end{array}$ & $(-)$ & China Statistic Yearbook \\
\hline
\end{tabular}


Table A1. Cont.

\begin{tabular}{|c|c|c|c|}
\hline Variable & Description & Expected Sign & Data Source \\
\hline$D G D P_{i j t} \times D S K I L L_{i j t}$ & $\begin{array}{l}\text { An interaction term between } \\
\text { the log of the difference of } \\
\text { GDP and the log of the } \\
\text { difference in the skills level }\end{array}$ & $(-)$ & $\begin{array}{l}\text { World Development } \\
\text { Indicators }\end{array}$ \\
\hline \multicolumn{4}{|c|}{ Inefficiency Determinants } \\
\hline $\operatorname{TRADECOST}_{i t}$ & $\begin{array}{l}\text { Trade costs for the home } \\
\text { country: } 100-\text { Tradefreedom } \\
\text { it }\end{array}$ & $(+)$ & Index of Economic Freedom \\
\hline $\operatorname{TRADECOST}_{j t}$ & $\begin{array}{l}\text { Trade costs for the host } \\
\text { country: } 100-\text { Tradefreedom } \\
\text { jt }\end{array}$ & $(-)$ & Index of Economic Freedom \\
\hline $\operatorname{INVCOST}_{j t}$ & $\begin{array}{l}\text { Investment costs for the host } \\
\text { country: } \\
\text { 100-Investmentfreedom }{ }_{j t}\end{array}$ & $(+)$ & Index of Economic Freedom \\
\hline$I N F R A_{j t}$ & $\begin{array}{l}\text { An index related to the road, } \\
\text { railways and water }\end{array}$ & $(-)$ & $\begin{array}{l}\text { World Development } \\
\text { Indicators }\end{array}$ \\
\hline$G O V E_{j t}$ & $\begin{array}{l}\text { The government effectiveness } \\
\text { of the host country }\end{array}$ & $(-)$ & Index of Economic Freedom \\
\hline POLITICAL $L_{j t}$ & $\begin{array}{l}\text { The political stability of the } \\
\text { host country }\end{array}$ & $(+)$ & Governance Indicators \\
\hline
\end{tabular}

\section{References}

1. Chen, C.L. Foreign Direct Investment in China: Location Determinants, Investor Behaviour and Economic Impact; Edward Elgar Publishing: Cheltenham, UK, 2011.

2. Tang, S.; Selvanathan, E.A.; Selvanathan, S. Foreign Direct Investment, Domestic Investment and Economic Growth in China: A Time Series Analysis. World Econ. 2008, 31, 1292-1309. [CrossRef]

3. Zhang, K.H. How does foreign direct investment affect economic growth in China? Econ. Transit. 2001, 9, 679-693. [CrossRef]

4. MOFCOM. Ministry of Commerce and Other Departments Jointly Issued the 2018 Statistical Bulletin of China's Outward Direct Investment. Available online: http:/ / fec.mofcom.gov.cn/article/tjsj/tjgb/201910/20191002907954.shtml (accessed on 15 January 2020).

5. WIR. World Investment Report 2018: Special Economic Zones; UN: Geneva, Switzerland, 2019.

6. Chang, L.; Cheong, K.C. Chinese Outward Foreign Direct Investment in Belt and Road Countries: Trends, Characteristics and Policies. Contemp. Chin. Political Econ. Strateg. Relat. Int. J. 2020, 6, 321-370.

7. Len, C. China's 21st Century Maritime Silk Road Initiative, Energy Security and SLOC Access. Marit. Aff. J. Natl. Marit. Found. India 2015, 11, 1-18. [CrossRef]

8. Cheng, L.K.H. Three questions on China's "Belt and Road Initiative". China Econ. Rev. 2016, 40, 309-313. [CrossRef]

9. Yu, H. Motivation behind China's 'One Belt, One Road' Initiatives and Establishment of the Asian Infrastructure Investment Bank. J. Contemp. China 2017, 26, 353-368. [CrossRef]

10. Du, J.; Zhang, Y. Does One Belt One Road initiative promote Chinese overseas direct investment? China Econ. Rev. 2018, 47, 189-205. [CrossRef]

11. Alon, I.; Wang, H.; Shen, J.; Zhang, W. Chinese state-owned enterprises go global. J. Bus. Strat. 2014, 35, 3-18. [CrossRef]

12. Amighini, A.; Rabellotti, R.; Sanfilippo, M. Do Chinese state-owned and private enterprises differ in their internationalization strategies? China Econ. Rev. 2013, 27, 312-325. [CrossRef]

13. Blomkvist, K.; Drogendijk, R. Chinese outward foreign direct investments in Europe. Eur. J. Int. Manag. 2016, 10, 343. [CrossRef]

14. Drysdale, P. A New Look at Chinese FDI in Australia. China World Econ. 2011, 19, 54-73. [CrossRef]

15. Buckley, P.J.; Casson, M. The Future of the Multinational Enterprise; Macmillan: London, UK, 1991.

16. Hymer, S.H.; Rugman, A.M. The International Operations of National Firms: A Study of Direct Foreign Investment; MIT Press: Cambridge, CA, USA, 1976.

17. Boddewyn, J.J. Foreign direct divestment theory: Is it the reverse of FDI theory? Rev. World Econ. 1983, 119, 345-355. [CrossRef]

18. Lall, S.; Siddharthan, N.S. The Monopolistic Advantages of Multinationals: Lessons from Foreign Investment in the U.S. Econ. J. 1982, 92, 668. [CrossRef]

19. Pitelis, C.N. Hymer, Stephen Herbert (1934-1974): The MNE and International Business. In The Palgrave Encyclopedia of Strategic Management; Augier, M., Teece, D.J., Eds.; Palgrave Macmillan: London, UK, 2018; pp. 686-691. 
20. Karlsson, C.; Nyström, K. Exit and Entry over the Product Life Cycle: Evidence from the Swedish Manufacturing Industry. Small Bus. Econ. 2003, 21, 135-144. Available online: http://www.jstor.org/stable/40229282 (accessed on 12 September 2020). [CrossRef]

21. Coase, R.H. The nature of the firm. Economica 1937, 4, 386-405. [CrossRef]

22. Buckley, P.J.; Casson, M. Future of the Multinational Enterprise; Springer: Berlin/Heidelberg, Germany, 1976.

23. Hennart, J.F. A Theory of Multinational Enterprise; University of Michigan Press: Ann Arbor, MI, USA, 1982.

24. Ayazlar, G. Internationalization of the Lodging Industry in the Light of Eclectic Paradigm. Procedia Econ. Financ. 2015, 26, 875-882. [CrossRef]

25. Dunning, J.H. The Eclectic Paradigm of International Production: A Restatement and Some Possible Extensions. J. Int. Bus. Stud. 1988, 19, 1-31. Available online: http:/ / www.jstor.org/stable/154984 (accessed on 21 January 2020). [CrossRef]

26. Dunning, J.H. Explaining changing patterns of international production: In defence of the eclectic theory. Oxf. Bull. Econ. Stat. 1979, 41, 269-295. [CrossRef]

27. Dunning, J.H. Explaining the international direct investment position of countries: Towards a dynamic or developmental approach. Weltwirtschaftliches Arch. 1981, 117, 30-64. [CrossRef]

28. Buckley, P.J.; Castro, F.B. The investment development path: The case of Portugal. Transnatl. Corp. 1998, 7, 1-16.

29. Duran, J.J.; Ubeda, F. The investment development path of newly developed countries. Int. J. Econ. Bus. 2005, 12, 123-137. [CrossRef]

30. Stoian, C. Extending Dunning's Investment Development Path: The role of home country institutional deter-minants in explaining outward foreign direct investment. Int. Bus. Rev. 2013, 22, 615-637. [CrossRef]

31. Kojima, K. Direct Foreign Investment: A Japanese Model of Multi-National Business Operations; Taylor \& Francis: Abingdon, UK, 2010.

32. Carr, D.L.; Markusen, J.R.; Maskus, K.E. Estimating the knowledge-capital model of the multinational enterprise. Am. Econ. Rev. 2001, 91, 693-708. [CrossRef]

33. Markusen, J.R. Multinational Firms and the Theory of International Trade; MIT Press: London, UK, 2004.

34. Meyer, K. What is "strategic asset seeking FDI"? Multinatl. Enterp. Emerg. Econ. 2015, 23, 57-66. [CrossRef]

35. Deng, P. Chinese Outward Direct Investment Research: Theoretical Integration and Recommendations. Manag. Organ. Rev. 2013, 9, 513-539. [CrossRef]

36. Kang, L.; Peng, F.; Zhu, Y.; Pan, A. Harmony in diversity: Can the one belt one road initiative promote China's outward foreign direct investment? Sustainability 2018, 10, 3264. [CrossRef]

37. Karreman, B.; Burger, M.J.; Van Oort, F.G. Location Choices of Chinese Multinationals in Europe: The Role of Overseas Communities. Econ. Geogr. 2017, 93, 131-161. [CrossRef]

38. Luo, Y.; Xue, Q.; Han, B. How emerging market governments promote outward FDI: Experience from China. J. World Bus. 2010, 45, 68-79. [CrossRef]

39. Buckley, P.J.; Clegg, L.J.; Cross, A.R.; Liu, X.; Voss, H.; Zheng, P. The determinants of Chinese outward foreign direct investment. J. Int. Bus. Stud. 2007, 38, 499-518. [CrossRef]

40. Han, J.; Chu, X.; Li, K. China's ODI Motivations, Political Risk, Institutional Distance and Location Choice. Theor. Econ. Lett. 2014, 4, 540-547. [CrossRef]

41. Dunning, J.H.; Lundan, S.M. Multinational Enterprises and the Global Economy; Edward Elgar: Cheltenham, UK, 2008.

42. Vivoda, V.; Manicom, J. Oil import diversification in Northeast Asia: A comparison between China and Japan. J. East Asian Stud. 2011, 11, 223-254. [CrossRef]

43. Wilson, J.D. Resource nationalism or resource liberalism? Explaining Australia's approach to Chinese investment in its minerals sector. Aust. J. Int. Aff. 2011, 65, 283-304. [CrossRef]

44. Zhou, W. Chinese Investment in Australia: A Critical Analysis of the China-Australia Free Trade Agreement. Melb. J. Int'l. L. 2017, 18, 407.

45. Dunning, J.H. Location and the multinational enterprise: A neglected factor? J. Int. Bus. Stud. 2009, 40, 5-19. [CrossRef]

46. Sethi, S.P.; Luther, K. Political Risk Analysis and Direct Foreign Investment: Some Problems of Definition and Measurement. Calif. Manag. Rev. 1986, 28, 57-68. [CrossRef]

47. Horst, T. The Simple Analytics of Multi-National Firm Behaviour. In International Trade and Money; Routledge: New York, NY, USA, 2018; pp. 72-84.

48. Agmon, T.; Hirsch, S. Multinational corporations and the developing economics: Potential gains in a world of imperfect markets and uncertainty. Oxf. Bull. Econ. Stat. 1979, 41, 333-344. [CrossRef]

49. Kljucnikov, A.; Junger, R. Barriers for Foreign Direct Investments in Belarus: Case of Business Logistics. In Proceedings of the Carpathian Logistics Congress, Cracow, Poland, 9-11 December 2013; pp. 139-145.

50. Khadaroo, A.J.; Seetanah, B. Transport infrastructure and foreign direct investment. J. Int. Dev. 2010, 22, 103-123. [CrossRef]

51. Pradhan, R.P.; Norman, N.R.; Badir, Y.; Samadhan, B. Transport Infrastructure, Foreign Direct Investment and Economic Growth Interactions in India: The ARDL Bounds Testing Approach. Procedia Soc. Behav. Sci. 2013, 104, 914-921. [CrossRef]

52. Bonnitcha, J. Foreign Investment, Development and Governance. What international investment law can learn from the empirical literature on investment. J. Int. Disput. Settl. 2016, 7, 31-57. [CrossRef]

53. Cai, D.; Wang, L.F.; Wu, X. Governance, privatization and foreign direct investment. Nankai Bus. Rev. Int. 2018, 9, 569-586. [CrossRef] 
54. Mishra, A.V.; Ratti, R.A. Governance, monitoring and foreign investment in Chinese companies. Emerg. Mark. Rev. 2011, 12, 171-188. [CrossRef]

55. Cornwell, C.; Schmidt, P. Stochastic Frontier Analysis and Efficiency Estimation. In The Econometrics of Panel Data: Fundamentals and Recent Developments in Theory and Practice; Mátyás, L., Sevestre, P., Eds.; Springer: Berlin/Heidelberg, Germany, 2008; pp. 697-726.

56. Stack, M.M.; Ravishankar, G.; Pentecost, E.J. FDI performance: A stochastic frontier analysis of location and variance determinants. Appl. Econ. 2015, 47, 1-14. [CrossRef]

57. Cheng, L.K.H.; Kwan, Y.K. What are the determinants of the location of foreign direct investment? The Chinese experience. J. Int. Econ. 2000, 51, 379-400. [CrossRef]

58. Cuyvers, L.; Soeng, R.; Plasmans, J.; Bulcke, D.V.D. Determinants of foreign direct investment in Cambodia. J. Asian Econ. 2011, 22, 222-234. [CrossRef]

59. Voss, H. The Determinants of Chinese Outward Direct Investment; Edward Elgar Publishing: Cheltenham, UK, 2011.

60. Wang, P. China's Outward Foreign Direct Investments and Impact on the World Economy; Palgrave Macmillan: London, UK, 2014.

61. Mukherjee, A.; Suetrong, K. Trade cost reduction and foreign direct investment. Econ. Model. 2012, 29, 1938-1945. [CrossRef]

62. Blonigen, B.A.; Piger, J. Determinants of foreign direct investment. Can. J. Econ. 2014, 47, 775-812. [CrossRef]

63. D'Agostino, R.B.; Belanger, A. A Suggestion for Using Powerful and Informative Tests of Normality. Am. Stat. 1990, 44, 316. [CrossRef]

64. Breusch, T.S.; Pagan, A.R. A Simple Test for Heteroscedasticity and Random Coefficient Variation. Econometrica 1979, $47,1287$. [CrossRef]

65. Caudill, S.B.; Ford, J.M.; Gropper, D.M. Frontier Estimation and Firm-Specific Inefficiency Measures in the Presence of Heteroscedasticity. J. Bus. Econ. Stat. 1995, 13, 105. [CrossRef]

66. Deng, P. Why do Chinese firms tend to acquire strategic assets in international expansion? J. World Bus. 2009, 44, 74-84. [CrossRef]

67. Wang, B.; Wang, H. Chinese manufacturing firms' overseas direct investment: Patterns, motivations and challenges'. In Rising China: Global Challenges and Opportunities; ANU Press: Canberra, Australia, 2011; pp. 99-119.

68. Lin, J.Y. “One Belt and One Road” and free trade zones-China's new opening-up initiatives. Front. Econ. China 2015, 10, 585-591.

69. Wang, J.; Wu, J.; Yao, X. The Expansion of Textile and Clothing Firms of China to Asian Least Developed Countries: The Case of Cambodia; Asia-Pacific Research and Training Network on Trade (ARTNeT): Bangkok, Thailand, 2008.

70. Deng, P. Outward investment by Chinese MNCs: Motivations and implications. Bus. Horiz. 2004, 47, 8-16. [CrossRef]

71. Wang, P.; Yu, Z. China's Outward Foreign Direct Investment: The Role of Natural Resources and Technology. Econ. Political Stud. 2014, 2, 89-120. [CrossRef]

72. Markusen, J.; Maskus, K. Multinational Firms: Reconciling Theory and Evidence. In Topics in Empirical International Economics: A Festschrift in Honor of Robert E. Lipsey; University of Chicago Press: Chicago, IL, USA, 2001; pp. 71-98.

73. Navaretti, G.B.; Venables, A.J.; Barry, F. Multinational Firms in the World Economy; Princeton University Press: Princeton, NJ, USA, 2006.

74. Xu, S.; He, L.; Ning, J.; Xiaotao, W.; Jing, C.; Ao, W.; Hu, Q. BRI and International Cooperation in Industrial Capacity: Country Cooperation Guide; Taylor \& Francis Group: Abingdon, UK, 2020.

75. Luo, Y.; Tung, R.L. International expansion of emerging market enterprises: A springboard perspective. J. Int. Bus. Stud. 2007, 38, 481-498. [CrossRef]

76. Meltzer, J.P. China's One Belt One Road Initiative: A View from the United States. Available online: https://www.brookings. edu/research/chinas-one-belt-one-road-initiative-a-view-from-the-united-states/ (accessed on 20 November 2020).

77. Sun, Y. Inserting Africa into China's One Belt, One Road Strategy: A New Opportunity for Jobs and Infrastructure. Available online: https:/ / www.brookings.edu/blog/africa-in-focus/2015/03/02/inserting-africa-into-chinas-one-belt-one-road-strategya-new-opportunity-for-jobs-and-infrastructure/ (accessed on 20 November 2020).

78. De Soyres, F.; Mulabdic, A.; Murray, S.; Rocha, N.; Ruta, M. How much will the Belt and Road Initiative reduce trade costs? Int. Econ. 2019, 159, 151-164. [CrossRef]

79. Song, L.; Yang, J.; Zhang, Y. State-owned Enterprises' Outward Investment and the Structural Reform in China. China World Econ. 2011, 19, 38-53. [CrossRef] 